Article

\title{
The Role of PXR Genotype and Transporter Expression in the Placental Transport of Lopinavir in Mice
}

\author{
Sarabjit S. Gahir ${ }^{1,2}$ and Micheline Piquette-Miller ${ }^{1, *}$ \\ 1 Leslie Dan Faculty of Pharmacy, University of Toronto, 144 College Street, Toronto, ON M5S 3M2, Canada; \\ sarabjit.gahir@gmail.com \\ 2 Reata Pharmaceuticals, Irving, TX 75063, USA \\ * Correspondence: m.piquette.miller@utoronto.ca; Tel.: +1-416-946-3057; Fax: +1-416-978-8511
}

Received: 2 October 2017; Accepted: 20 October 2017; Published: 24 October 2017

\begin{abstract}
Lopinavir (LPV), an antiretroviral protease inhibitor frequently prescribed in HIV-positive pregnancies, is a substrate of $A b c b 1$ and $A b c c 2$. As differences in placental expression of these transporters were seen in Pregnane X Receptor (PXR) - / - mice, we examined the impact of placental transporter expression and fetal PXR genotype on the fetal accumulation of LPV. PXR + / - dams bearing PXR +/+, PXR +/ - , and PXR $-/$ - fetuses were generated by mating PXR $+/-$ female mice with PXR +/ - males. On gestational day 17 , dams were administered $10 \mathrm{mg} / \mathrm{kg}$ LPV (i.v.) and sacrificed $30 \mathrm{~min}$ post injection. Concentrations of LPV in maternal plasma and fetal tissue were measured by LC-MS/MS, and transporter expression was determined by quantitative RT-PCR. As compared to the PXR +/ + fetal units, placental expression of Abcb1a, Abcc2, and Abcg2 mRNA were two- to three-fold higher in PXR $-/-$ fetuses $(p<0.05)$. Two-fold higher fetal:maternal LPV concentration ratios were also seen in the PXR $+/+$ as compared to the PXR $-/-$ fetuses $(p<0.05)$, and this significantly correlated to the placental expression of Abcb1a $(r=0.495 ; p<0.005)$. Individual differences in the expression of placental transporters due to genetic or environmental factors can impact fetal exposure to their substrates.
\end{abstract}

Keywords: antiretrovirals; transporters; P-glycoprotein; breast cancer resistance protein; multidrug resistance associated protein; gene regulation; protease inhibitor; Pregnane X Receptor; placenta; knockout mice

\section{Introduction}

Globally, there are over 2 million children living with HIV and, according to UNAIDS, most of these infections were caused by mother-to-child transmission (MTCT) of the virus [1]. Employing a strategy of aggressive, proactive prophylaxis when managing HIV-seropositive pregnancies by the administration of Highly Active Anti-Retroviral Therapy (HAART) has brought the rate of vertical transmission down from around $25 \%$ in the absence of these interventions to less than $2 \%$ in North America [2,3]. However, little is known about the factors controlling the transplacental trafficking of highly potent antiretrovirals.

The placenta is the principle gateway between the maternal and fetal systems, regulating the exchange of both endogenous and exogenous molecules. This barrier site also performs a critical role in limiting the access of potentially toxic xenobiotics [4,5]. The presence of several ATP Binding Cassette $(\mathrm{ABC})$ drug transporters, including P-glycoprotein (PGP/ABCB1), Multidrug Resistance Associated Proteins (MRP/ABCC), and the Breast Cancer Resistance Protein (BCRP/ABCG2) at the materno-placental interface, is believed to be involved in the extrusion of a wide spectrum of drugs including antiretrovirals [6-9]. Indeed, the fetal accumulation of the protease inhibitor saquinavir has been found to be elevated in PGP-deficient mice models [10]. 
Lopinavir (LPV) is currently a second-line protease inhibitor (PI) that is frequently used in managing HIV-positive pregnancies [11,12]. Several in vitro and in vivo studies have established the involvement of $\mathrm{ABCB} 1$ and $\mathrm{ABCC} 2$ in the transport of LPV during the processes of absorption and disposition [13-17]. Inhibition or deficiency of PGP, which is encoded by Abcb1a and Abcb1b in rodents, has been shown to increase the oral bioavailability of LPV in addition to increasing its concentrations in the central nervous system (CNS). The placental transfer of PIs such as LPV has been shown to be highly variable in patients, in that it has been reported that the fetal cord to maternal plasma concentrations for LPV range from 0.05 to 0.34 [18-20]. Given the established role of drug transporters in LPV transport, the variability in the placental expression of these transporters may play an important part in inter- or intra-subject variability in the placental transfer of LPV into fetal tissues.

The expression of many drug transporters in the placenta has been shown to vary throughout gestation. Reports indicate that levels of PGP decline while levels of BCRP increase as gestation progresses [21-23]. The situation is further complicated by reports of disease-mediated alterations of drug transporters. In a study comparing the placental expression of PGP in HIV-infected and uninfected women, dramatically higher PGP expression was seen in placental tissue obtained from HIV-positive patients [24]. Alterations in the expression of the key drug efflux transporters in the placenta could have a serious clinical impact. In the case of drugs such as antiretrovirals, a fine balance between efficacy and safety needs to be struck, given the interplay between drug concentration, viral load suppression, and MTCT on one hand, and the potential for fetal drug toxicity on the other. Thus, it is important to be able to predict how genetic, environmental, or pathophysiological influences impact fetal drug exposure.

Nuclear receptors such as the Pregnane $X$ Receptor (PXR) are known to be key regulators of $A B C$ drug transporters such as Abcb1, Abcc2, Abcc3, and Abcg2 [25-28]. It is well known that PXR is activated by endogenous steroidal hormones and their metabolites, the levels of which are dramatically elevated during pregnancy. PXR is also activated by a number of dietary components, herbal remedies, and clinically important drugs [29,30]. Genetic polymorphisms of PXR are associated with decreased expression of the target genes encoding $\mathrm{ABCB} 1$ and CYP3A4 in patients, resulting in altered clearance of drug substrates [31,32]. While PXR activation and subsequent transporter induction at the liver and blood brain barrier has been shown to alter the bio-availability and CNS accumulation of many therapeutic agents, its role in determining fetal drug disposition is unclear and largely unexplored.

We have previously demonstrated a tissue-specific role for PXR in mice [33]. Several PXR target genes (Abcb1a, Abcc1-3, and Abcg2) were found to be elevated in the placenta in PXR null mice, with dramatically higher levels of placental transporters in the PXR $-/-$ mice as compared to the PXR $+/+$ mice. As the functional units of the placenta are almost entirely derived from fetal tissues, it is the fetal genotype that dictates the placental genotype and is therefore responsible for regulating the expression of placental transporters [34]. In this manner, alterations of fetal PXR genotype could provide us with a unique murine model with clear differences in placental transporter levels within the same dam. Therefore, by breeding PXR heterozygotes $(+/-)$, we generated a PXR $+/-$ dam bearing PXR $+/+$, PXR $+/-$, and PXR $-/-$ fetuses and placentas, allowing us to examine the impact of a range of placental transporter expression on substrate drug accumulation in the fetal units while maintaining a similar maternal physiological environment. This strategy enabled us to examine the relative contribution of placental transporters on LPV disposition without confounding maternal influences. Using this model, we explored the role of fetal PXR genotype and placental drug transporter expression on the fetal accumulation of LPV.

\section{Materials and Methods}

\subsection{Animals and Experimental Design}

All animal studies were in accordance with the guidelines of the Canadian Council of Animal Care. PXR heterozygote (+/-) animals were obtained by crossing PXR $-/-$ females with PXR 
+/+ males. PXR wild type $(+/+)$ C57/BL6 mice were purchased from Charles River Canada (Montreal, QC, Canada). The PXR knockout (-/-) C57/BL6 mice were obtained with approval from Dr. Steven Kliewer (University of Texas, Southwestern Medical Center, Dallas, TX, USA) as described previously [35]. For the purpose of obtaining timed pregnancies, the PXR +/- male mice were paired overnight with PXR $+/-$ females, and the male removed the following morning contingent to observance of a vaginal plug. On gestational day (GD) 17, pregnant PXR +/ - animals were administered $10 \mathrm{mg} / \mathrm{kg}$ LPV intravenously (i.v.) via tail vein (Lopinavir; USP, Rockville, MD, USA). LPV was dissolved in ethanol:propylene glycol: 5\% dextrose solution (2:4:4 ratio). Animals were sacrificed at $30 \mathrm{~min}$ post injection and maternal plasma and fetal tissues were collected for analysis. Previously, we found that maximal fetal accumulation occurs at 30 min after LPV i.v. administration in healthy rats [36] and pilot studies in PXR +/ - mice established that this time point was optimal in detecting LPV in both maternal and fetal samples. The plasma was stored at $-20^{\circ} \mathrm{C}$, while the fetal and placental tissues were snap frozen and stored at $-80^{\circ} \mathrm{C}$ until analysis. The fetal units were genotyped for PXR by PCR from DNA isolated from placenta and visualizing the PCR products on a $2 \%$ agarose gel. The PXR genotype did not impact fetal survival nor fetal weight (PXR + / +: $0.72 \pm 0.05 \mathrm{~g}$; PXR +/ -: $0.69 \pm 0.02 \mathrm{~g}$; PXR -/ -: $0.75 \pm 0.06 \mathrm{~g}$ ).

\subsection{Analysis of Transporter mRNA Expression}

Methods for RNA isolation, cDNA synthesis, qRT-PCR, and primer sequences have been described previously [35]. Briefly, total RNA was extracted from placental tissue using the QuickPrep RNA extraction kit (Amersham Biosciences Inc., Piscataway, NJ, USA). RNA was quantified on a NanoDrop ND-1000 spectrophotometer (Thermo Fisher Scientific, Waltham, MA, USA) and then reverse-transcribed to cDNA by use of a first-strand cDNA synthesis kit (Fermentas, Burlington, ON, Canada) according to manufacturer's protocol. qRT-PCR quantification of Abcb1a (Mdr1a), Abcc2 (Mrp2), and Abcg2 (Bcrp) mRNA were carried out by qPCR using Roche LightCycler technology with the LC FastStart DNA Master SYBR Green I Kit (Roche, Laval, QC, Canada). Oligonucleotides for previously reported primer sequences were synthesized at The Hospital for Sick Children (DNA Synthesis Centre, Toronto, ON, Canada). All transcript levels were normalized to the housekeeping gene, cyclophilin, using the efficiency-corrected $\triangle \mathrm{Cq}$ qPCR method, and the ratios are presented as the percentage of control values. Normalization to either Gapdh or $18 \mathrm{~S}$ rRNA was found to give comparable results, and cyclophilin levels were not significantly different between genotypes. Abcb1b (Mdr1b) was very poorly expressed in the placenta of our mice, with expression in most samples being below the detectable limit. As a result, Abcb1b mRNA levels are not reported.

\subsection{Lopinavir LC-MS/MS Analysis}

LPV concentrations in maternal plasma and fetal tissue samples were quantified using LC-MS/MS as previously described [36]. Briefly, maternal plasma and fetal tissue samples were thawed to room temperature. Tissue samples were homogenized in glass tubes with deionized water. Then, $100 \mu \mathrm{L}$ of plasma or fetal tissue homogenates were added into tubes containing the internal standard, ritonavir (USP, Rockville, MD, USA). Sample extraction was performed using liquid-liquid extraction. Briefly, $50 \mu \mathrm{L}$ of $500 \mathrm{mM}$ sodium carbonate was mixed with the samples followed by adding $1.2 \mathrm{~mL}$ of hexane/ethyl acetate $(1: 1 \mathrm{v} / \mathrm{v})$. The mixture was then vortexed for $2 \mathrm{~min}$, centrifuged at $21,000 \mathrm{~g}$ for $15 \mathrm{~min}$ at $4{ }^{\circ} \mathrm{C}$, and the organic layer $(700 \mu \mathrm{L})$ was transferred to clean vials, evaporated under nitrogen gas, and reconstituted in $200 \mu \mathrm{L}$ of $80 \%$ methanol. The final extracts were aliquoted into autosampler vials. Unless otherwise noted, all chemical reagents were purchased from Sigma-Aldrich (Oakville, ON, Canada).

The LC-MS/MS system employed a CTC PAL autosampler unit (LEAP Technologies, Carrboro, NC, USA) with an Agilent 1100 series pump (Agilent Technologies, Santa Carla, CA, USA). Elution was achieved using a $50 \mathrm{~mm} \times 4.6 \mathrm{~mm}, 5 \mu \mathrm{m}$ Lichrosorb RP-8 column (Phenomenex, Torrance, CA, USA) with a mobile phase of $20: 80$ parts of $0.1 \%$ formic acid to $80 \%$ methanol (flow rate $0.700 \mathrm{~mL} / \mathrm{min}$ ). 
MS/MS was performed with an API 4000 triple quadrupole MS equipped with a TurbolonSpray source and was set to the positive reaction monitoring mode (AB Sciex, Concord, ON, Canada). MRM transitions for LPV were $m / z 629.3$ to $m / z 447.3$ and for ritonavir, the internal standard, were $m / z$ 721.3 to $m / z 268$, with the source temperature set to $500{ }^{\circ} \mathrm{C}$. Analyst software version 1.4.2 was used (Applied Biosystems/MDS Sciex) for the analysis and quantification of LPV. The lower limit of LPV detection was $<3 \mathrm{ng} / \mathrm{mL}$ and the lower limit of quantification was $<10 \mathrm{ng} / \mathrm{mL}$.

\subsection{Statistical Analysis}

Data were analyzed using GraphPad Prism (GraphPad Software version 5.0c, San Diego, CA, USA). Statistical significance was determined by analysis of variance (ANOVA) and significance was set to $p<0.05$. Results are expressed as means \pm standard error (SE). Pearson correlation $(r)$ was used to analyze the strength of linear relationships between fetal LPV accumulation and transporter expression levels, and both the Pearson correlation $\mathrm{r}$ and absolute $p$-values are reported.

\section{Results}

\subsection{Impact of Fetal PXR Genotype on Transporter Expression}

As compared to the PXR +/+ fetal units, the placental mRNA expression of Abcb1a, Abcc2, and Abcg2 was approximately two- to three-fold higher in the PXR - / - fetal units (Figure 1). The expression of these transporters was significantly different in placentas obtained from PXR $-/$ - fetal units as compared to PXR $+/+$ fetal units $(p<0.05)$.

Intermediate levels of these transporters were seen in fetal units with the PXR $+/-$ genotype. While levels of Abcb1a in the PXR +/ - placentae were significantly different from the PXR $+/+$ fetal units $(p<0.05)$, levels were not significantly different from the PXR $-/-$ units. This provided us with an animal model with varying placental expression of transporters within the same dam.

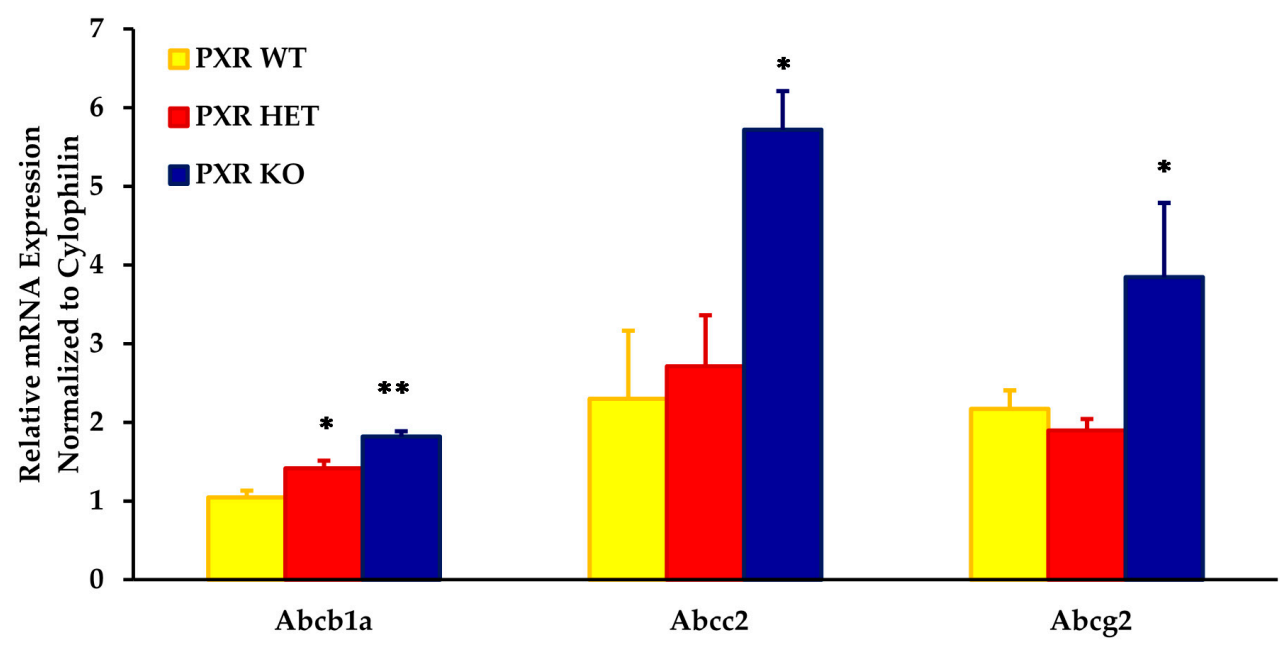

Figure 1. Effect of fetal genotype on basal mRNA expression of key placental transporters on GD 17. Fetal genotypes are PXR +/+ (PXR WT), PXR +/ - (PXR HET), and PXR - / - (PXR KO). Placental mRNA expression was measured using RT-PCR and normalized to cyclophilin. Values are presented as relative expression levels \pm S.E. ${ }^{*} p<0.05 ;{ }^{* *} p<0.01$ compared to PXR WT. $n=10$.

\subsection{Impact of Fetal PXR Genotype on Fetal Accumulation of LPV}

We saw significant differences in the fetal tissue accumulation of LPV between the PXR $+/+$ and PXR - / - fetal units (Figure 2). The fetal tissue:maternal plasma LPV concentration was approximately $50 \%$ lower in the PXR $-/-$ fetuses as compared to the PXR $+/+$ units $(p<0.05)$. There was, however, no statistically significant differences in LPV accumulation between the PXR $+/+$ and PXR $+/-$ fetuses. 


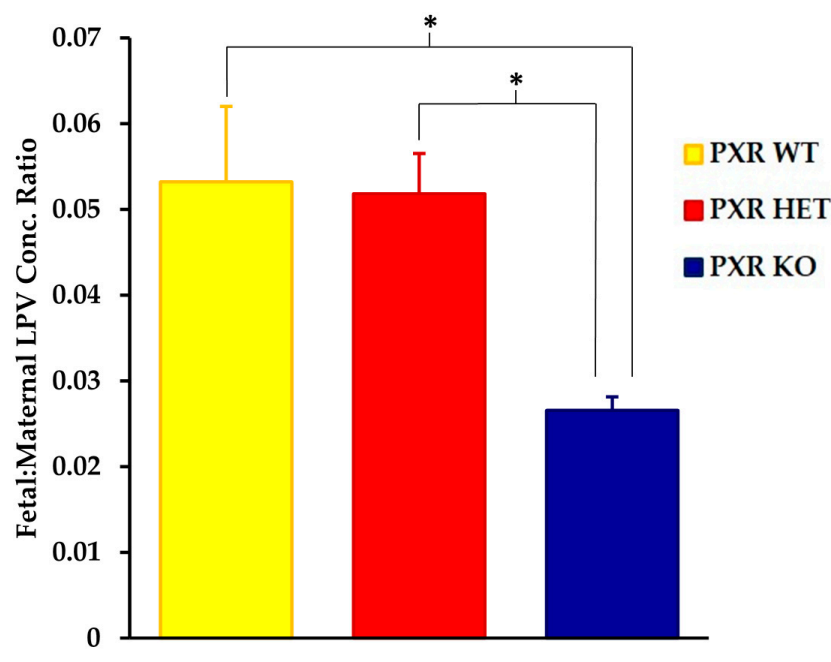

Figure 2. Effect of fetal genotype on LPV accumulation in fetal tissue. LPV concentration ratios were quantified by LC-MS/MS 30 min post-intravenous injection of LPV (10 mg/ $\mathrm{kg}$ ) as stated in the Materials and Methods section. Concentration ratios were calculated as the concentration ratio of LPV in fetal homogenate per unit weight (ng/g) to maternal plasma concentrations (ng/mL). Values are given as mean ratios \pm S.E. ${ }^{*} p<0.05 . n=10$.

\subsection{Relationship of Fetal Drug Accumulation and Transporter Expression}

We observed a highly significant correlation between the placental mRNA expression of Abcb1a in all fetal genotypes and the fetal accumulation of LPV (Figure 3A). There was a clear association of lower fetal tissue:maternal plasma concentration ratios with increased Abcb1a expression. A linear regression best fit the data, and the equation describing the data was $y=15.38 x+3.3(p=0.0016)$.

There was a strong trend with Abcc2 in that higher transcript levels of Abcc2 tended to be associated with lower fetal tissue:maternal plasma concentration ratios (Figure 3B). However, this association failed to reach significance $(p=0.055)$. The data were best described with a linear regression fit, with the equation of the line of best fit being $y=1.82 x+14$. Of note, we found that the placental mRNA expression of Abcc 2 was highly and significantly correlated to the expression of Abcb1a $(r=0.54 ; p=0.0007)$. No significant correlation (linear or polynomial) between Abcg2 expression and LPV fetal accumulation was detected (Figure 3C).

(A)

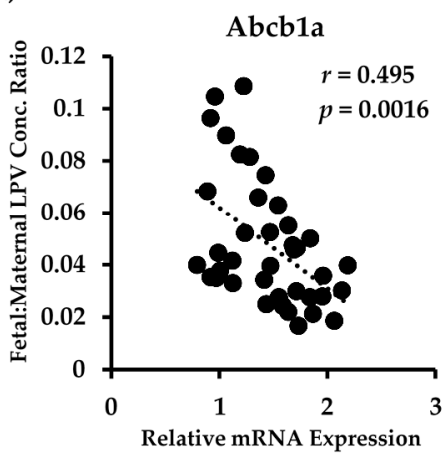

(B)

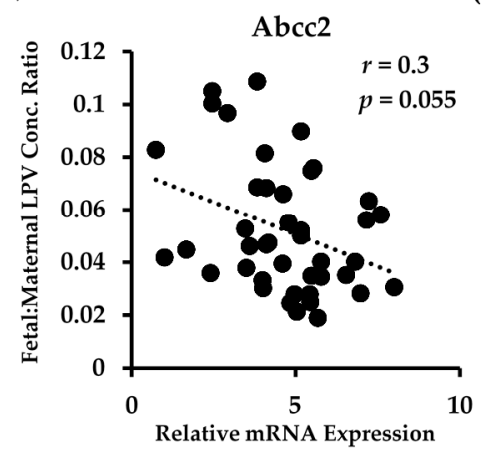

(C)

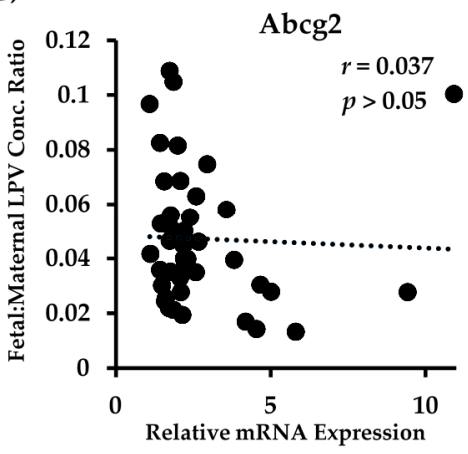

Figure 3. Relationship between fetal accumulation of LPV and placental expression of (A) Abcb1a; (B) Abcc2; and (C) Abcg2 in all fetal PXR genotypes. Fetal accumulation is represented as the LPV concentration of fetal homogenate $(\mathrm{ng} / \mathrm{g}$ ) relative to maternal plasma concentration $(\mathrm{ng} / \mathrm{mL})$. Relative placental mRNA expression was determined as described in the Materials and Methods section. $n=39$. 


\section{Discussion}

Many studies to date have reported low and highly variable placental transfer of protease inhibitors at delivery. While numerous in vitro and ex vivo studies have explored the role of placental transporters in drug transport, relatively little is still known about their genetic, environmental, and pathophysiological regulation, or the impact that changes in transporter expression have on fetal drug exposure. Our findings demonstrate that fetal PXR genotype affects the placental expression of drug transporters with a corresponding effect on fetal drug exposure. In this study, we found that the expression of three key ABC drug transporters, Abcb1a, Abcc2, and Abcg2, were significantly lower in fetal units with the PXR + / genotype as compared to the PXR - / - genotype. Additionally, we found a corresponding change in the accumulation of LPV in that the fetal-maternal concentration ratios in fetuses with the PXR +/+ genotype was approximately two times higher than those seen in the PXR $-/-$ fetuses. These findings indicate that PXR genotypes that influence placental expression of transporters can also affect the fetal exposure to their substrates.

In vitro and in vivo studies have previously demonstrated that LPV is transported by PGP, which is primarily encoded by Abcb1a in murine placenta. Our model provided us with a four-fold range in the placental expression of Abcb1a between fetal units of different genotypes while maintaining a similar maternal environment. With an increase in the transcription level of placental Abcb1a, we saw a distinct decrease in the fetal accumulation of LPV. Moreover, the fetal accumulation of LPV was significantly correlated to Abcb1a expression, illustrating the important role of placental PGP on fetal exposure to LPV. These findings are in line with an ex vivo perfused human placental study that demonstrated that the inhibition of PGP increased the fetal to maternal transfer of LPV up to 10-fold [37]. Pathophysiological changes in placental Abcb1 expression were also found to significantly alter maternal-fetal transfer of LPV in rat models of infection and gestational diabetes $[36,38]$.

We observed a very low and frequently undetectable placental expression of Abcb1b in all PXR genotypes. While PGP is encoded by Abcb1a and Abcb1b in rodents, it has been previously demonstrated that Abcb1a is the functional isoform in murine placenta. Studies in Abcb1a- and Abcb1b-deficient mice demonstrated that fetal exposure of PGP substrates such as digoxin were dependent on Abcb1a but not Abcb1b expression [39]. Moreover, only fetuses from dams with reduced Abcb1a expression (Abcb1a $-/-$ or $+/-$ ) were susceptible to avermectin-induced cleft palate teratogenicity, despite uniform Abcb1b placental expression [40]. This highlights Abcb1a as the vital and functional isoform of PGP in mouse placenta.

The efflux transporter $\mathrm{ABCC} 2$, which is localized on the apical surface of the placenta, has also been shown to mediate placental transfer of its drug substrates such as talinolol [41]. Fetal:maternal concentration ratios of LPV tended to be lower, albeit non-significant, in fetal units with higher placental levels of $A b c c 2$, suggesting possible involvement in the placental transport of LPV. However, the contribution of ABCC2 to the in vivo disposition of LPV is not clearly known. ABCC2 has been shown to transport LPV at low concentrations in vitro in transfected cell lines [14]. However, using knockout mice models, van Waterschoot et al. (2010) demonstrated that PGP but not ABCC2 significantly influenced the oral bioavailability of LPV [17]. As we found a strong association between the expression of Abcb1a and Abcc2, it is likely that the trend between Abcc2 expression and LPV fetal accumulation was due to the fact that placentas that expressed higher levels of Abcc2 also expressed higher levels of Abcb1a as a function of the PXR genotype, rather than implicating an active role of ABCC2 in placental LPV transport. While ABCG2 is highly expressed in the placenta and plays a key role in limiting maternal-fetal transport of potentially toxic xenobiotics, LPV is not a substrate of ABCG2 [14,42]. In line with previous data, we did not observe a significant association between the fetal accumulation of LPV and Abcg2 expression. However, LPV is a potent inhibitor of ABCG2 [43]. Therefore, given the importance of ABCG2 in fetal protection and its broad range of drug substrates, the potential for drug-drug interactions should be further explored. This is particularly important when considering the clinical scenario where pregnant HIV-positive patients receive numerous antiviral agents. 
Interestingly, while we found significant differences in the placental expression of transporters between the PXR + / + and PXR - / - fetal genotypes, these differences were not as great as those seen in our previous study [33]. For instance, while we previously saw a 12-fold higher expression of Abcb1a in the placenta of PXR - / - dams as compared to PXR +/+ dams, only a two-fold difference was seen in the placental expression between the PXR +/+ and PXR - / - fetuses. This may be due to the fact that while all three genotypes were generated within a single PXR +/ - mother in this study, the previous study used homozygote PXR mating pairs to generate the three PXR genotypes (i.e., PXR $+/+$ parents to generate PXR +/+ fetus, PXR $-/-$ parents to generate $-/-$ fetus, and PXR $-/-$ and PXR $+/+$ mating pair to generate PXR $+/-$ fetus). Thus, the maternal environment to which the different PXR genotypic placentas were exposed were unique and likely had an impact on the expression of PXR target genes. It is well known that progesterone is an activator of PXR and levels of this steroid hormone increase throughout pregnancy. Moreover, PXR, along with other nuclear receptors, is believed to play a role in hormonal homeostasis and may subsequently regulate transporters through hormonal changes $[44,45]$. Therefore, differences in genotype as well as the physiological hormone environment may influence placental transporter expression in the different dams.

In conclusion, our data demonstrates the importance of PGP expression in limiting the fetal accumulation of an important antiretroviral agent. Hence inter-individual differences in the expression of placental transporters due to genetic or environmental factors can impact fetal exposure to their substrates. The situation is further confounded by the fact that expression may be further affected by pathophysiological changes due to HIV infection or other co-morbidities. Alterations can lead to either unexpected fetal accumulation or inadequate therapeutic levels, both resulting in poor fetal outcomes. The current model can be used to study the in vivo impact of placental transporter expression on the fetal exposure to a wide array of drugs, thus helping to bridge a critical knowledge gap in the area of drug usage in pregnancy.

Acknowledgments: Funding for this study was provided by an operating grant from the Canadian Institutes of Health Research [MOP 13346]. The authors thank Ms. Eliza McColl for her assistance in the preparation of the manuscript and design of the graphical abstract.

Author Contributions: Micheline Piquette-Miller and Sarabjit S. Gahir conceived and designed the experiments; Sarabjit S. Gahir performed the experiments; Sarabjit S. Gahir analyzed the data; Micheline Piquette-Miller and Sarabjit S. Gahir wrote the paper.

Conflicts of Interest: The authors declare no conflict of interest.

\section{Abbreviations}

$\begin{array}{ll}\text { ABC } & \text { ATP Binding Cassette } \\ \text { BCRP } & \text { Brest Cancer Resistance Protein } \\ \text { CNS } & \text { Central Nervous System } \\ \text { GD } & \text { Gestational Day } \\ \text { HAART } & \text { Highly Active Antiretroviral Therapy } \\ \text { HIV } & \text { Human Immunodeficiency Virus } \\ \text { I.V. } & \text { Intravenously } \\ \text { LC-MS/MS } & \text { Liquid Chromatography-Tandem Mass Spectrometry } \\ \text { LPV } & \text { Lopinavir } \\ \text { MRP } & \text { Multidrug Resistance Associated Protein } \\ \text { MTCT } & \text { Mother-to-Child Transmission } \\ \text { PI } & \text { Protease Inhibitor } \\ \text { PXR } & \text { Pregnane X Receptor } \\ \text { qRT-PCR } & \text { Quantitative Real Time Polymerase Chain Reaction }\end{array}$




\section{References}

1. HIV. Gov. Available online: https:/ / www.hiv.gov/federal-response/pepfar-global-aids/global-hiv-aidsoverview (accessed on 27 September 2017).

2. Sturt, A.S.; Dokubo, E.K.; Sint, T.T. Antiretroviral therapy (ART) for treating HIV infection in ART-eligible pregnant women. Cochrane Database Sys. Rev. 2010, 3, CD008440. [CrossRef]

3. Van Dyke, R.B. Mother-to-child transmission of HIV-1 in the era prior to the availability of combination antiretroviral therapy: The role of drugs of abuse. Life Sci. 2011, 88, 922-925. [CrossRef] [PubMed]

4. Prouillac, C.; Lecoeur, S. The role of the placenta in fetal exposure to xenobiotics: Importance of membrane transporters and human models for transfer studies. Drug Metab. Dispos. 2010, 38, 1623-1635. [CrossRef] [PubMed]

5. Syme, M.R.; Paxton, J.W.; Keelan, J.A. Drug transfer and metabolism by the human placenta. Clin. Pharmacokinet. 2004, 43, 487-514. [CrossRef] [PubMed]

6. Vähäkangas, K.; Myllynen, P. Drug transporters in the human blood-placental barrier. Br. J. Pharmacol. 2009, 158, 665-678. [CrossRef] [PubMed]

7. Ni, Z.; Mao, Q. ATP-binding cassette efflux transporters in human placenta. Curr. Pharm. Biotechnol. 2010, 12, 674-685. [CrossRef]

8. Tomi, M.; Nishimura, T.; Nakashima, E. Mother-to-fetus transfer of antiviral drugs and the involvement of transporters at the placental barrier. J. Pharm. Sci. 2011, 100, 3708-3718. [CrossRef] [PubMed]

9. Hutson, J.R.; Garcia-Bournissen, F.; Davis, A.; Koren, G. The human placental perfusion model: A systemic review and development of a model to predict in vivo transfer of therapeutic drugs. Clin. Pharmacol. Ther. 2011, 90, 67-76. [CrossRef] [PubMed]

10. Huisman, M.T.; Smit, J.W.; Wiltshire, H.R.; Hoetelmans, R.M.; Beijnen, J.H.; Schinkel, A.H. P-glycoprotein limits oral availability, brain, and fetal penetration of saquinavir even with high doses of ritonavir. Mol. Pharmacol. 2001, 59, 806-813. [PubMed]

11. Navér, L.; Albert, J.; Belfrage, E.; Flamholc, L.; Gisslén, M.; Gyllensten, K.; Yilmaz, A. Prophylaxis and treatment of HIV-1 infection in pregnancy: Swedish recommendations 2010. Scand. J. Infect. Dis. 2011, 43, 411-423. [CrossRef] [PubMed]

12. Baroncelli, S.; Tamburrini, E.; Ravizza, M.; Dalzero, S.; Tibaldi, C.; Ferrazzi, E.; Anzidei, G.; Fiscon, M. Italian Group on Surveillance on Antiretroviral Treatment in Pregnancy. Antiretroviral treatment in pregnancy: A six-year perspective on recent trends in prescription patters, viral load suppression, and pregnancy outcomes. AIDS Patient Care STDS 2009, 23, 513-520. [CrossRef] [PubMed]

13. Janneh, O.; Jones, E.; Chandler, B.; Owen, A.; Khoo, S.H. Inhibition of P-glycoprotein and multidrug resistance-associated proteins modulates the intracellular concentration of lopinavir in cultured CD4 T cells and primary human lymphocytes. J. Antimicrob. Chemoth. 2007, 60, 987-993. [CrossRef] [PubMed]

14. Agarwal, S.; Pal, D.; Mitra, A.K. Both P-gp and MRP2 mediate transport of lopinavir, a protease inhibitor. Int. J. Pharm. 2007, 339, 139-147. [CrossRef] [PubMed]

15. Gulati, A.; Gerk, P.M. Role of placental ABC transporters in antiretroviral therapy during pregnancy. J. Pharm. Sci. 2009, 98, 2317-2335. [CrossRef] [PubMed]

16. Kim, A.E.; Dintaman, J.M.; Waddell, D.S.; Silverman, J.A. Saquinavir, an HIV protease inhibitor, is transported by P-glycoprotein. J. Pharmacol. Exp. Ther. 1998, 286, 1439-1445. [PubMed]

17. Van Waterschoot, R.A.; ter Heine, R.; Wagenaar, E.; van der Kruijssen, C.M.; Rooswinkel, R.W.; Huitema, A.D.; Schinkel, A.H. Effects of cytochrome P450 3A (CYP3A) and the drug transporters P-glycoprotein (MDR1/ABCB1) and MRP2 (ABCC2) on the pharmacokinetics of lopinavir. Br. J. Pharmacol. 2010, 160, 1224-1233. [CrossRef] [PubMed]

18. Marzolini, C.; Rudin, C.; Decosterd, L.A.; Telenti, A.; Schreyer, A.; Biollaz, J. Swiss Mother + Child HIV Cohort Study. Transplacental passage of protease inhibitors at delivery. AIDS 2002, 16, 889-893. [CrossRef] [PubMed]

19. Mirochnick, M.; Capparelli, E. Pharmacokinetics of antiretrovirals in pregnant women. Clin. Pharmacokinet. 2004, 43, 1071-1087. [CrossRef] [PubMed] 
20. Yeh, R.F.; Rezk, N.L.; Kashuba, A.D.; Dumond, J.B.; Tappouni, H.L.; Tien, H.C.; Patterson, K.B. Genital tract, cord blood, and amniotic fluid exposures of seven antiretroviral drugs during and after pregnancy in human immunodeficiency virus type 1-infected women. Antimicrob. Agents Chemother. 2009, 53, 2367-2374. [CrossRef] [PubMed]

21. Sun, M.; Kingdom, J.; Baczyk, D.; Lye, S.J.; Matthews, S.G.; Gibb, W. Expression of the multidrug resistance P-glycoprotein, (ABCB1) in the human placenta decreases with advancing gestation. Placenta 2006, 27, 602-609. [CrossRef] [PubMed]

22. Gil, S.; Saura, R.; Forestier, F.; Farinotti, R. P-glycoprotein expression of the human placenta during pregnancy. Placenta 2005, 26, 268-270. [CrossRef] [PubMed]

23. Yeboah, D.; Sun, M.; Kingdom, J.; Baczyk, D.; Lye, S.J.; Matthews, S.G.; Gibb, W. Expression of breast cancer resistance protein (BCRP/ABCG2) in human placenta throughout gestation and term before and after labor. Can. J. Physiol. Pharmacol. 2006, 84, 1251-1258. [CrossRef] [PubMed]

24. Camus, M.; Deloménie, C.; Didier, N.; Faye, A.; Gil, S.; Dauge, M.C.; Farinotti, R. Increased expression of MDR1 mRNA and P-glycoprotein in placentas from HIV-1 infected women. Placenta 2006, 27, 699-706. [CrossRef] [PubMed]

25. Kliewer, S.A.; Goodwin, B.; Willson, T.M. The nuclear Pregnane X Receptor: A key regulator of xenobiotic metabolism. Endocr. Rev. 2002, 23, 687-702. [CrossRef] [PubMed]

26. Teng, S.; Piquette-Miller, M. Regulation of transporters by nuclear hormone receptors: Implications during inflammation. Mol. Pharmaceut. 2008, 5, 67-76. [CrossRef] [PubMed]

27. Teng, S.; Jekerle, V.; Piquette-Miller, M. Induction of ABCC3 (MRP3) by Pregnane X Receptor activators. Drug Metab. Dispos. 2003, 31, 1296-1299. [CrossRef] [PubMed]

28. Anapolsky, A.; Teng, S.; Dixit, S.; Piquette-Miller, M. The role of Pregnane X Receptor in 2-acetylaminofluorene-mediated induction of drug transport and metabolizing enzymes in mice. Drug Metab. Dispos. 2006, 34, 405-409. [CrossRef] [PubMed]

29. Chang, T.K.; Waxman, D.J. Synthetic drugs and natural products as modulators of constitutive androstane receptor (CAR) and Pregnane X Receptor (PXR). Drug Metab. Rev. 2006, 38, 51-73. [CrossRef] [PubMed]

30. Kliewer, S.A.; Moore, J.T.; Wade, L.; Staudinger, J.L.; Watson, M.A.; Jones, S.A.; Lehmann, J.M. An orphan nuclear receptor activated by pregnanes defines a novel steroid signaling pathway. Cell 1998, 92, 73-82. [CrossRef]

31. Sandanaraj, E.; Lal, S.; Selvarajan, V.; Ooi, L.L.; Wong, Z.W.; Wong, N.S.; Ang, P.C.; Lee, E.J.; Chowbay, B. PXR pharmacogenetics: Association of haplotypes with hepatic CYP3A4 and ABCB1 messenger RNA expression and doxorubicin clearance in Asian breast cancer patients. Clin. Cancer Res. 2008, 14, 7116-7126. [CrossRef] [PubMed]

32. Schipani, A.; Siccardi, M.; D’Avolio, A.; Baietto, L.; Simiele, M.; Bonora, S.; Rodríguez Novoa, S.; Cuenca, L.; Soriano, V.; Chierakul, N.; et al. Population pharmacokinetic modeling of the association between 63396C->T Pregnane X Receptor polymorphism and unboosted atazanavir clearance. Antimicrob. Agents Chemother. 2010, 54, 5242-5250. [CrossRef] [PubMed]

33. Gahir, S.S.; Piquette-Miller, M. Gestational and Pregnane X Receptor-mediated regulation of placental ATP-binding cassette drug transporters in mice. Drug Metab. Dispos. 2011, 39, 465-471. [CrossRef] [PubMed]

34. Daud, A.; Bergman, J.; Bakker, M.; Wang, H.; de Walle, H.; Plosch, T. Pharmacogenetics of drug-induced birth defects; the role of polymorphisms of placental transport proteins. Pharmacogenomics 2014, 15, 1029-1041. [CrossRef] [PubMed]

35. Teng, S.; Piquette-Miller, M. The involvement of the Pregnane X Receptor in hepatic gene regulation during inflammation in mice. J. Pharmacol. Exp. Ther. 2005, 312, 841-848. [CrossRef] [PubMed]

36. Anger, G.; Piquette-Miller, M. Mechanisms of reduced maternal and fetal lopinavir exposure in a rat model of gestational diabetes. Drug Metab. Dispos. 2011, 39, 1850-1859. [CrossRef] [PubMed]

37. Ceccaldi, P.F.; Gavard, L.; Mandelbrot, L.; Rey, E.; Farinotti, R.; Treluyer, J.M.; Gil, S. Functional role of P-glycoprotein and binding protein effect on the placental transfer of lopinavir/ritonavir in the ex vivo human perfusion model. Obstet. Gynecol. Int. 2009, 2009, 726593. [CrossRef] [PubMed]

38. Petrovic, V.; Piquette-Miller, M. Polyinosinic/Polycytidylic Acid-mediated changes in maternal and fetal disposition of lopinavir in rats. Drug Metab. Dispos. 2015, 43, 951-957. [CrossRef] [PubMed] 
39. Schinkel, A.H.; Mayer, U.; Wagenaar, E.; Mol, C.A.; van Deemter, L.; Smit, J.J.; van der Valk, M.A.; Voordouw, A.C.; Spits, H.; van Tellingen, O.; et al. Normal viability and altered pharmacokinetics in mice lacking mdr1-type (drug-transporting) P-glycoproteins. Proc. Natl. Acad. Sci. USA 1997, 94, 4028-4033. [CrossRef] [PubMed]

40. Lankas, G.R.; Wise, L.D.; Cartwright, M.E.; Pippert, T.; Umbenhauer, D.R. Placental P-glycoprotein deficiency enhances susceptibility to chemically induced birth defects in mice. Reprod. Toxicol. 1998, 12, 457-463. [CrossRef]

41. May, K.; Minarikova, V.; Linnemann, K.; Zygmunt, M.; Kroemer, H.K.; Fusch, C.; Siegmund, W. Role of the multidrug transporter proteins $\mathrm{ABCB} 1$ and $\mathrm{ABCC} 2$ in the placental transport of talinolol in the term human placenta. Drug Metab. Dispos. 2008, 36, 740-744. [CrossRef] [PubMed]

42. Hahnova-Cygalova, L.; Ceckova, M.; Staud, F. Fetoprotective activity of breast cancer resistance protein (BCRP, ABCG2): Expression and function throughout pregnancy. Drug Metab. Rev. 2011, 43, 53-68. [CrossRef] [PubMed]

43. Weiss, J.; Rose, J.; Storch, C.H.; Ketabi-Kiyanvash, N.; Sauer, A.; Haefeli, W.E.; Efferth, T. Modulation of human BCRP (ABCG2) activity by anti-HIV drugs. J. Antimicrob. Chemother. 2007, 59, 238-245. [CrossRef] [PubMed]

44. Sonoda, J.; Xie, W.; Rosenfeld, J.M.; Barwick, J.L.; Guzelian, P.S.; Evans, R.M. Regulation of a xenobiotic sulfonation cascade by nuclear Pregnane X Receptor (PXR). Prac. Natl. Acad. Sci. USA 2002, 99, 13801-13806. [CrossRef] [PubMed]

45. Kliewar, S.A.; Lehmann, J.M.; Milburn, M.V.; Willson, T.M. The PPARs and PXRs: Nuclear xenobiotic receptors that define novel hormone signaling pathways. Recent Prog. Horm. Res. 1999, 54, 345-367.

(C) 2017 by the authors. Licensee MDPI, Basel, Switzerland. This article is an open access article distributed under the terms and conditions of the Creative Commons Attribution (CC BY) license (http:/ / creativecommons.org/licenses/by/4.0/). 